\title{
Anti-Cancer Activity And Anti-Proliferation Ant Nests Flavonoid Fraction Test (Myrmecodya Pendans) Human Tongue Cancer Cells In Sp-C1
}

\author{
Harun Achmad $^{1 *}$, Suryani A. Armyn ${ }^{2}$, Supriatno $^{3}$, Marhamah F. Singgih ${ }^{1}$ \\ Lecturer, Pediatric Dentistry Department, Faculty of Dentistry, Hasanuddin University \\ Lecturer, Clinical Nutrition Department, Faculty of Medicine, Hasanuddin University \\ Lecturer, Oncology and Oral Medicine Department, Faculty of Dentistry, Gadjah Mada University
}

\begin{abstract}
Squamous cell carcinoma of the tongue is a malignant tumor derived from epithelial mucosa of the oral cavity and is largely a type of epidermoid carcinoma. The purpose of the study is to identify and analyze the effect of the flavonoid fraction of ant nests (Myrmecodia pendans) as an anti-cancer barrier against proliferation through Akt signaling and barrier mechanism of NF-KB in cancer cells SP-Cl of the tongue.

The results of the study showed that the cytotoxicity test had the highest concentration of $1000 \mu \mathrm{g} / \mathrm{ml}$ to the lowest concentration of $7.8125 \mu \mathrm{g} / \mathrm{ml}$ in ethyl acetate fraction, ethanol, hexan fraction and water generates significant percentage data of the tongue cancer cell death SP-Cl. Ethyl acetate flavonoid fraction in a concentration of $1000 \mu \mathrm{g} / \mathrm{ml}$ caused the percentage of cell death as much as $64.60 \%$, and the lowest concentration of $7.8125 \mu \mathrm{g} / \mathrm{ml}$ led to cell death as much as $15.80 \%$. LC50 values of ethyl acetate fraction, ethanol fraction, hexan fraction and water fraction, respectively for $452.059 \mu \mathrm{g} / \mathrm{ml} ; 937.562 \mu \mathrm{g} / \mathrm{ml} ; 2691.535$ $\mu \mathrm{g} / \mathrm{ml} ; 12302.69 \mu \mathrm{g} / \mathrm{ml}$. Analysis antiproliferative flavonoid fraction and ethyl acetate fraction of ethanol based on concentration and incubation time to absorption optical density SP-Cl cells was statistically highly significant $(p=0.00)$.
\end{abstract}

Keywords: Tongue squamous cell carcinoma SP-Cl, ant nests' flavonoid fraction, proliferation.

\section{Introduction}

Cancer is a disease with characteristic disruption or failure of regulatory mechanisms in multicellular organisms multiplication resulting in changes in cell behavior that are not controlled. The changes are due to changes or genetic transformation, especially in the genes that regulate growth, namely proto-oncogene and tumor suppressor genes. The cells that undergo continuous transformation proliferate and suppress the growth of normal cells. Cancer is a disease with high mortality rates. ${ }^{[1]}$ Data Global Action Against Cancer Fund of the World Health Organization (WHO) states that cancer deaths could reach 45\% from 2007 to 2030, which is about 7.9 million to 11.5 million deaths. In Indonesia, according to a Riskesdas report cancer prevalence at 4.3 per 1,000 population, and the seventh cause of death $(5.7 \%)$ after stroke, tuberculosis, hypertension, trauma, perinatal and diabetes mellitus. ${ }^{[2]}$

Squamous cell carcinoma is the most common type of cancer that occurs in the oral cavity which is about $90-95 \%$ of total malignancy in the oral cavity. Location squamous cell carcinoma of the oral cavity is usually located on the tongue (ventral and lateral), lips, floor of the mouth, buccal mucosa, and retromolar area. ${ }^{[3]}$ Squamous cell carcinoma of the tongue is a malignant tumor derived from epithelial mucosa of the oral cavity and is largely a type of epidermoid carcinoma. Squamous cell carcinoma of the tongue ranged between 25 and $50 \%$ of all malignant cancers in the mouth. ${ }^{[4]}$

Several studies have proven the efficacy of ant nests for the treatment of cancer, it was revealed after the ant nest herbs can be used as an alternative medicine breast cancer chemotherapy with minimal side effects. Treatment with ant nests traditional medicine does not take a lot of cost and has minimal side effects compared to chemotherapy which requires a lot of cost and have many side effects. ${ }^{[5]}$

Chemical screening test ant nests plant (Myrmecodia pendans) shows that this plant contains the chemical compounds of the flavonoid and tannin. Many mechanisms of flavonoid that has been revealed, including carcinogen inactivation, antiproliferation, cell cycle inhibition, induction of apoptosis and differentiation, and inhibition of angiogenesis. Ant nests ability empirically for the treatment of various types of cancer or tumors, allegedly related to the flavonoid content of ant nests. ${ }^{[5,6]}$

Flavonoids are polyphenolic compounds found as an essential component of the human diet. ${ }^{[5]}$ According Kandaswami $\mathrm{C}$ et al flavonoids are a substitute phenyl chromones (benzopyran derivatives) which consists of the basic framework of carbon-15 (C6-C3-C6), consisting of chromones (C6-C3), core (benzo ring $\mathrm{A}$ and ring heterocyclic $\mathrm{C}$ ), also shared by tocopherols, with phenyl (aromatic ring B) substitution at 2-position normally. ${ }^{[7]}$ Different substitution can usually occur in ring A and B. In vivo study showed that the flavonoids in 
certain foods have antitumor activity. Hydroxylation pattern in ring B of flavones and flavonols, such as luteolin and quercetin affect protein kinase inhibition and antiproliferative activity. Flavonols and flavones targeting signal transduction enzymes surface cell, such as protein tyrosine kinase and focal adhesion kinase (FAK), and the process of angiogenesis being targeted as a promising anticancer drug. ${ }^{[8]}$ Ant nests contain flavonoids, tannins and polyphenols that act as antioxidants, so it is good for cancer prevention. In addition, ant nests also contain tocopherol and alpha-tocopherol, the substances with high activity capable of inhibiting free radicals. ${ }^{[9]}$ Supri's-clone cell (SP-C1) has been studied to obtain anticancer compounds from medicinal plants (herbs) as well as the effectiveness of synthetic drugs on the growth of cancer cells. $S P-C l$ is a tongue cancer cells isolated from nodes lymph of patients with tongue cancer, derived from squamous cell carcinoma and has medium differentiate not experienced invasion yet into muscle tissue. ${ }^{[10]}$

\section{Materials And Methods}

The research was done by purely experimental laboratory using cultured human tongue cancer cells Supri's-Clone (SP-C1). The study was conducted at the Laboratorium Penelitian dan Pengujian Terpadu (LPPT) Gadjah Mada University in Yogyakarta from July to October 2013. Ant plants originated from Jayawijaya, Papua. Fresh ant nests as much as 900 grams being extracted using ethanol and subsequently evaporated to produce ethanol extract. Ethanol extract concentrated then dissolved in distilled water and then partitioned in a separating funnel using $n$-hexane to obtain the fraction of $n$-hexane and water $\left(\mathrm{H}_{2} \mathrm{O}\right)$. Water fractions obtained subsequently partitioned between water, ethyl acetate and ethanol yield ethyl acetate and ethanol fraction.

Cytotoxicity test in this study was performed by incubating the cells with a number of $2 \times 10^{4}$ cells for 24 hours with serial concentrations of ant nests flavonoids. The analysis used the MTT (3-(4,5 dimethyl thiazol2-yl)-2.5-diphenyltetrazolium bromide), a tetrazolium salt that is commonly used in the quantitative determination of living mammalian cells or proliferation calorimetry method in vitro, the method only be used on live cells and not in dead cell, because it is based on the degree of cell activation. The concentration of ant nests flavonoids in the cytotoxicity test with the interval number $1000 \mu \mathrm{g} / \mathrm{ml}$ for the upper limit, $7.812 \mu \mathrm{g} / \mathrm{ml}$ for the lower limit and at successive intervals of $7.812 \mu \mathrm{g} / \mathrm{ml}, 18.625 \mu \mathrm{g} / \mathrm{ml}, 31.25 \mu \mathrm{g} / \mathrm{ml}, 62.5 \mu \mathrm{g} / \mathrm{ml}, 125$ $\mu \mathrm{g} / \mathrm{ml}, 250 \mu \mathrm{g} / \mathrm{ml}, 500 \mu \mathrm{g} / \mathrm{ml}, 1000 \mu \mathrm{g} / \mathrm{ml}$, and $0 \mu \mathrm{g} / \mathrm{ml}$ as a control.

Testing proliferation barriers to treatment flavonoid ethyl acetate and ethanol fraction is carried out based on the data absorbance of living viable cells in an ELISA reader optical density measurements of $550 \mathrm{~nm}$. The results of measurements on cell proliferation barriers to treatment flavonoid ethyl acetate ethanol fraction is then performed to create table of relationships mean relative number of cells with concentrations of SP-Cl is of a concentration of $500 ; 250 ; 125 ; 62.5 ; 31.25$, and $15.625 \mu \mathrm{g} / \mathrm{ml}$ and control cells.

\section{Result And Discussion}

The results of the study showed cytotoxicity test tongue cancer cell death percentage of SP-C1 from each treatment fraction continues to increase coincide with the increase of the given concentration. Ethyl acetate and ethanol fraction resulted in the most potential cell growth inhibition compared with hexan fraction and water fraction. Ethyl acetate fraction of flavonoids at a concentration of $1000 \mu \mathrm{g} / \mathrm{ml}$ resulted in the percentage of cell death as much as $64.60 \%$, and the lowest concentration of $7.8125 \mu \mathrm{g} / \mathrm{ml}$ led to cell death by $15.80 \%$ of the cells. The graph results of the average percentage number of cell death due to exposure to certain concentrations of four fractions (Fig. 1).

Graph showing the relationship of concentration with a mean $\%$ cell death

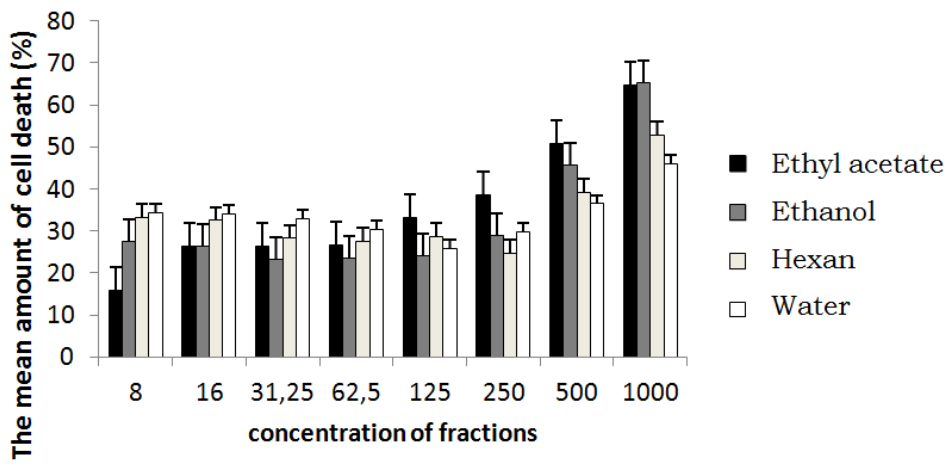

Figure 1 Effect of cytotoxic ant nests (Myrmecodia pendans) ethyl acetate, ethanol, hexan, and water hexan fraction to tongue cancer cells SP-C1. 
Research results by cytotoxicity test obtained LC50 of each fraction consisting of ethyl acetate fraction, ethanol fraction, hexan fraction and water fraction, respectively, 452.059; 937.562; 2691.535; $12302.69 \mu \mathrm{g} / \mathrm{ml}$. These results were obtained from the equation of the line curve log concentration vs. probit. This study refers to the standard of Meyer which states that a substance said to be active or to have toxic properties when LC50 values $<1000 \mu \mathrm{g} / \mathrm{ml}$ for extracts and $\leq 30 \mu \mathrm{g} / \mathrm{ml}$ of the compound. An extract is considered toxic when the LC50 value $30-1000 \mu \mathrm{g} / \mathrm{ml}$ and is not considered toxic when LC50 values above $1000 \mu \mathrm{g} / \mathrm{ml}$. The toxicity level gave interpretation of potential antitumor activity. LC50 is used as a parameter to identify the potential cytotoxicity of the flavonoid fraction of ant nests $S P$-C1 tongue cancer cells. The smaller LC50, the more toxic compound. Because the value of LC50 levels of ant nests flavonoids ethyl acetate fraction of $452.059 \mu \mathrm{g} / \mathrm{ml}$, and ant nests ethanol fraction at a concentration of $937.562 \mu \mathrm{g} / \mathrm{ml}$, indicating that the concentration of this fraction was below the $1000 \mu \mathrm{g} \mathrm{ml}$, it can be concluded that the fraction of ant nests ethyl acetate and ethanol fraction have cytotoxic activity against tongue cancer cells $S P-C l$ based on Meyer criteria (Fig. 2).

The result of proliferation inhibition cell $S P-C l$ with ethyl acetate fraction treatment suggests that inhibition of cell growth are based on the concentration given, starting from the lowest concentration of 15.625 $\mu \mathrm{g} / \mathrm{ml}$ to the highest concentration that is $500 \mu \mathrm{g} / \mathrm{ml}$. Similarly, the factors incubation time 24,48 and 72 hours showed that the longer the incubation, the greater the inhibition of growth of cells.

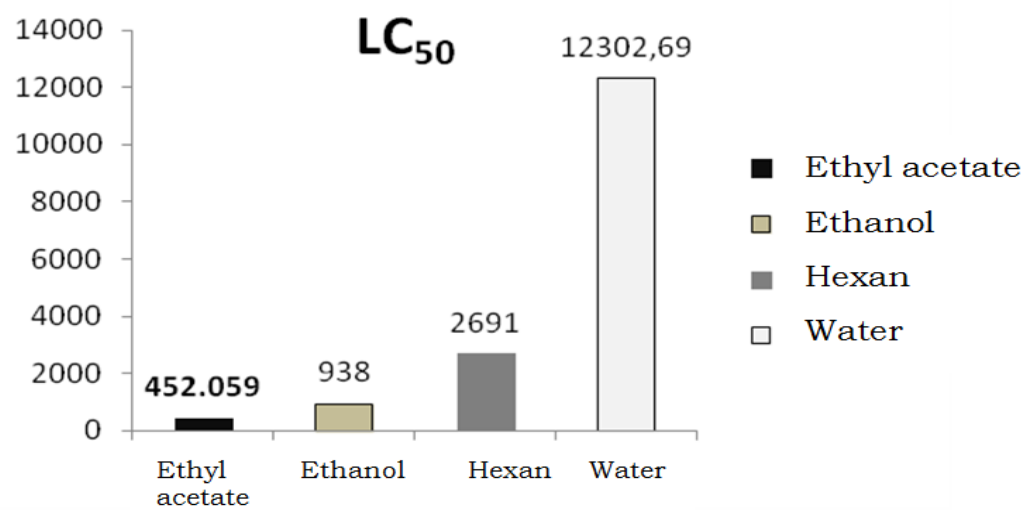

Figure 2 Results of cytotoxicity assay LC50 in each flavonoid fraction.

Based on the results obtained (Fig. 3), it appears that in general the flavonoid ethyl acetate and ethanol fraction has a cell growth inhibitory activity of SP-C1, as shown in the measurement of SP-C1 cells using ELISA reader. Seen the effect of the fraction of some larger concentrations compared with the control growth barriers. The larger the concentration, the smaller the sample of living cells, growth inhibition evident at a concentration of $500 \mu \mathrm{g} / \mathrm{mL}$, by inhibiting the activity cell proliferation of SP-C1.

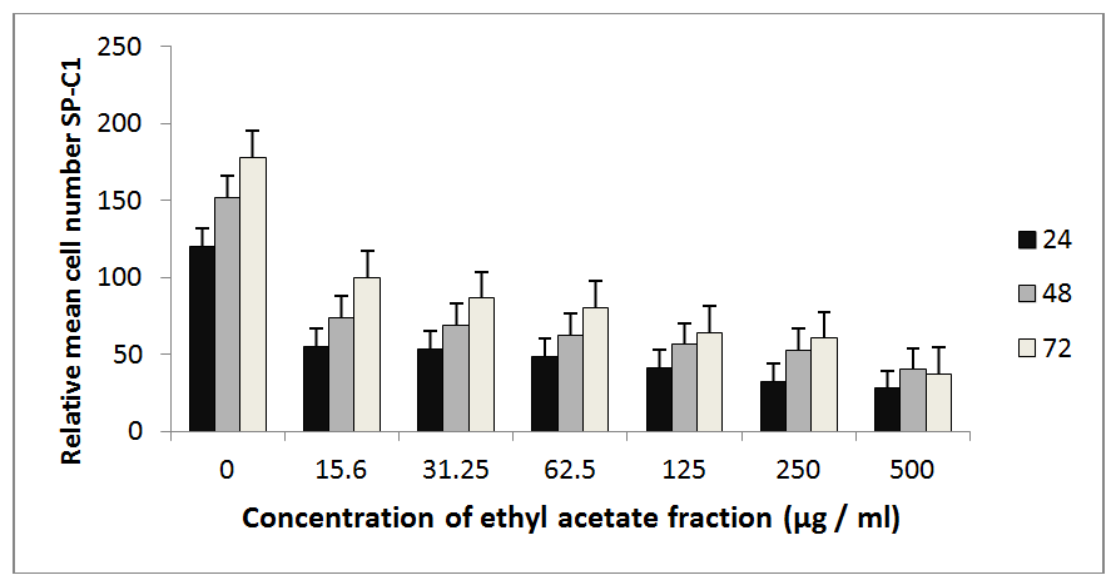

Figure 3. Tongue cancer cell $S P-C l$ growth profile proliferation assay results from the ant nests ethyl acetate fraction at 24,48 and 72 hours.

Treatment flavonoid ethyl acetate and ethanol fraction against tongue cancer cells $S P$ - $C l$ based on given concentration showed a decrease in the number of cells that seen from concentration of $15,625 \mu \mathrm{g} / \mathrm{ml}$ to 
a concentration of $500 \mu \mathrm{g} / \mathrm{ml}$ which means there is a cell growth inhibition (Fig. 4), but thus treatment of flavonoid ethyl acetate and ethanol fraction of the tongue cancer cells $S P-C l$ based on incubation time to be otherwise is an increase in the number of cells from 24 to 48 to 72 hour, an increase in cell number is not as high as the control of cell growth. In Fig. 3, ethyl acetate treatment, a concentration of $500 \mu \mathrm{g} / \mathrm{ml} \mathrm{based} \mathrm{on}$ incubation time appears preceded by an increase in the number of cells of $27.79 \%$ on the 24 th hour to $40.15 \%$ at the 48th hour. But at the 72nd hour the number of cells decline becomes $37.36 \%$ which means that cells burn out and experiencing saturation. It so happens in Fig. 4 the treatment of ethanol, a concentration of $500 \mu \mathrm{g} / \mathrm{ml}$ based on incubation time preceded by an increase in the number of cells of $24.89 \%$ on the 24 th hour to $40.54 \%$ at the 48th hour. But at the 72nd hour decline in the number of cells becomes $31.14 \%$, which means the cells burn out and experiencing saturation. This death can occur through a mechanism of arrest (cell cycle arrest that normally occurs in phases G1/S).

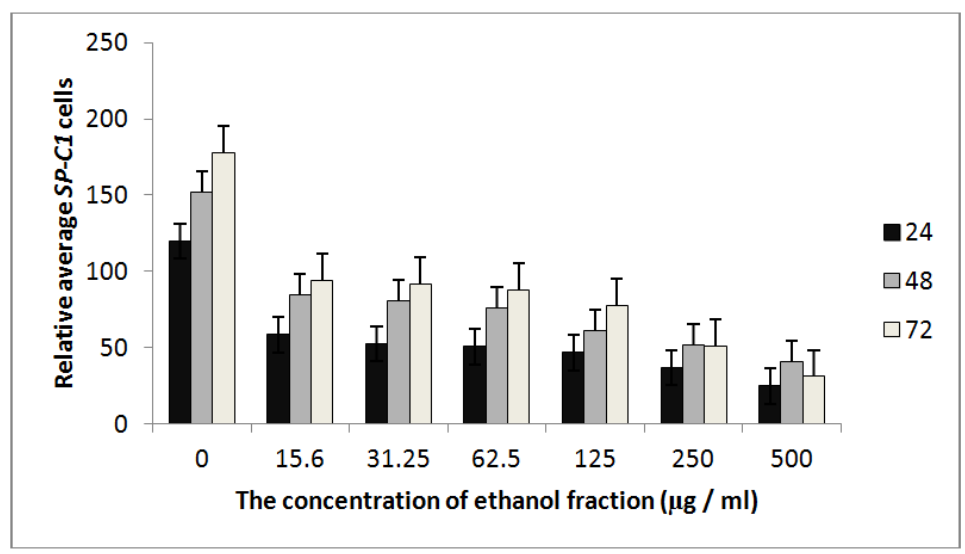

Figure 4. Profile growth proliferation assay tongue cancer cell $S P-C l$ results from theant nests ethanol fraction at 24,48 and 72 hours.

The results of these studies is in line with previous research that has been done to extract of the ant nests contains flavonoids and tannins with demonstrated growth inhibition against HeLa cells and MCM-B2 cells. ${ }^{[9]}$ The results of other studies conducted by Hertiani et al showed that the ant nests ethyl acetate fraction have immunomodulatory effects, namely the provision of ant nests ethyl acetate fraction on the effect of lymphocyte proliferation $\mathrm{BALB} / \mathrm{c}$ mice in vitro.

The results of this study which confirms that the ant nests flavonoid fraction has a barrier on the proliferation of tongue cancer cells SP-C1 supported theoretically that flavonoids can inhibit the performance of all the CDK that is cell cycle regulator. Point of flavonoid lies in the inhibition of the enzyme CdkActivatingKinase/CAK thus inhibiting the formation of active Cyclin-CDK complexes. Flavonoids can bind to the protein kinase on the ATP-binding site. ${ }^{[1,12]}$ Checkpoint at the G1/S and G2/M disturbed by the presence of flavonoids. Flavonoids inhibit the signal transduction of growth factors. Flavonoids are able to inactivate proteins that play a role in signal transduction, such as tyrosine kinase. ${ }^{[13,14,15]}$ These statements explain the possibility of the induction of cell cycle arrest by the role of flavonoids.

Flavonoid compounds contained in herbal medicines have the effect of blocking the receptors of growth factors, inhibited Mitogen Activated Protein Kinase (MAPK), on the Receptor Tyrosine Kinase signaling pathways (RTKs). In H. Deguchi Research, states that the flavonoid compounds contained in herbal medicine (green tea) have growth inhibitory effects on breast cancer cells (T47D cells). The mechanism of inhibition of growth was mainly on MAPK with phosphorilated various proteins including transcription factors that required in the synthesis of proteins in differentiation and cell cycle and cycle.

\section{Conclusion}

Ant nests flavonoid fraction has potential anti-cancer on tongue cancer cells $(S P-C 1)$ type of Squamous Cell Carcinoma. Ant nests flavonoid fraction has an inhibition effect on the proliferation of tongue cancer cells $(S P-C 1)$. Growth inhibition of tongue cancer cell SP-C1 for $57.90 \%$ of the ethyl acetate fraction and $61.13 \%$ of the ethanol fraction. 


\section{References}

[1]. $\quad$ King RJ, Robing MW. Cancer biology. $3^{\text {rd }}$ ed. England; Pearson Education Limited: 2006. p. 209-29

[2]. Soendoro T. Laporan Riskesdas 2007. Kementerian Kesehatan Republik Indonesia: 2008

[3]. Regezi JA, Sciubba JJ. Oral pathology, clinical pathologic correlations. $3^{\text {rd }}$ ed. Philadelphia; WB Saunders Co.: 1999. p. 76-90

[4]. Hasibuan S. Prosedur deteksi dini dan diagnosis kanker rongga mulut. Digitized by USU digital library: 2004. p. 1-7

[5]. Subroto A, Saputro H. Gempur penyakit dengan sarang semut. Jakarta; PT Agromedia Pustaka: 2007

[6]. Simanjuntak P, Fanny, Subroto MA. Isolasi senyawa aktif dari ekstrak hipokotil sarang semut (Myrmecodia pendans) sebagai penghambat xantinoksidase. Jurnal Ilmu Kefarmasian Indonesia. 2010: 49-54

[7]. Fayette J, Soria JC, Armand JP. Use of angiogenesis inhibitors in tumour treatment. Eur J Cancer. 2005; 41(8): 1109-16

[8]. Robbins SL, Kumar V, Cotran RS. Robbin's basic pathology. $7^{\text {th }}$ ed. Philadelphia; WB Saunders Co.: 2005. p. $309-13$

[9]. Soeksmanto MA, Subroto HW, Simanjuntak P. Anticancer activity test for extracts of sarang semut plant (myrmecodya pendans) to HeLa and MCM-B2 cells. Pakistan Journal of Biological Sciences; 13: 148-51

[10]. Supriatno, Yuletnawati. Aktivitas anti kanker cepharantine pada kanker lidah manusia in vitro (tinjauan proliferasi, invasi, dan metastesis sel. Majalah Kedokteran Gigi UGM. 2006: 141-5

[11]. Chavakis E, Dimmeler S. Regulation of endothelial cell survival and apoptosis during engiogenesis. Arterioscler Thromb Vasc Biol. 2002; 22(6): 887-93

[12]. Folkman J. The role of angiogenesis. Semin Oncol. 2002; 29(6): 15-8

[13]. Neville BW, Damm DD, Alien CM, Bouquot IE. Oral and maxillofacial pathology. $2^{\text {nd }}$ ed. Philadelphia; WB Saunders Co.: 2002. p. $61-75$

[14]. Praga SM, Dickson RB, Hawkins MJ. Matrix metalloproteinase inhibitors. J Investigational New Drug. 2002; 15: 61-75

[15]. Kumar V, Cotran RS, Robbins SL. Basic pathology. $7^{\text {th }}$ ed. Philadelphia; WB Saunders Co.: 2003. p. 61-78, 165-210 